\title{
Foraminifera from the lower Eocene Sakesar Limestone at Nammal, western Salt Range, northern Pakistan
}

\author{
S.J. Sameeni and A.A. Butt \\ Institute of Geology, Punjab University \\ Lahore, Pakistan
}

\begin{abstract}
Study of the Sakesar Limestone of the lower Eocene age in the Nammal Gorge in western Salt Range is carried out. During the field investigation eight samples were collected from an $80 \mathrm{ft}$ thick limestone horizon, at equal interval. A new Alveolinid, foraminifera assemblage is identified.
\end{abstract}

\section{INTRODUCTION}

The lower Eocene succession in and around the Nammal Gorge in the western Salt Range comprises the Nammal Limestone and Shale and the Sakesar Limestone (Fig. 1).

The Sakesar Limestone was named by Gee (1935) from its type locality at Mount Sakesar $\left(32^{\circ} 31^{\prime} \mathrm{N}, 71^{\circ} 56^{\prime} \mathrm{E}\right)$. This formation is typically nodular in off-white colour containing frequent chert nodules. Several age-diagnostic larger foraminifera can be observed on the weathered surface. Its stratigraphic position in relation to the adjoining areas of the Kala Chitta and Hazara Mountains is shown in Fig. 2.

Eight samples were collected from the Sakesar Limestone (approximately $80 \mathrm{ft}$. thick) at an equal interval from bottom to top along the Mianwali-Talagang Road in the neighbourhood of the famous Nammal Gorge. The Nammal Gorge itself exposes an excellent stratigraphic sequence from Permian to Recent except some depositional gaps, one at the base of the Paleocene (marked by the laterite) and the other between the lower Eocene Sakesar Limestone and the non-marine Miocene to
Pleiocene sediments collectively known as the Siwaliks.

From the Sakesar Limestone, Davies and Pinfold (1937) reported a larger foraminiferal assemblage including Nummulites mamillatus (Fichtel and Moll, 1798), Nummulites atacicus Leymerie, 1846, Assilina granulosa (d'Archiac, 1847), Assilina spinosa Davies and Pinfold, 1937, Lockhartia tipperi (Davies, 1932) and Alveolina globosa Leymerie, 1846.

\section{PRESENT WORK AND FINDINGS}

In the present study, a total of 48 thin sections were examined and the following larger foraminiferal species were identified (Fig. 3 and 4): Alveolina globula Hottinger, 1971, Nummulites mamillatus, Nummulites atacicus, Nummulites sp., Assilina spinosa, Assilina laminosa Gill, 1953, Assilina granulosa, Alveolina pasticillata Schwager, 1883, Alveolina sp., Alveolina ellipsoidalis Schwager, 1883, Ranikothalia sindensis (Davies, 1927), Discocyclina dispansa Sowerby, 1840, Discocyclina ranikotensis (Davies, 1927), Lockhartia tipperi (Davies, 1932) and Lockhartia conditi (Nuttal, 1926). The 


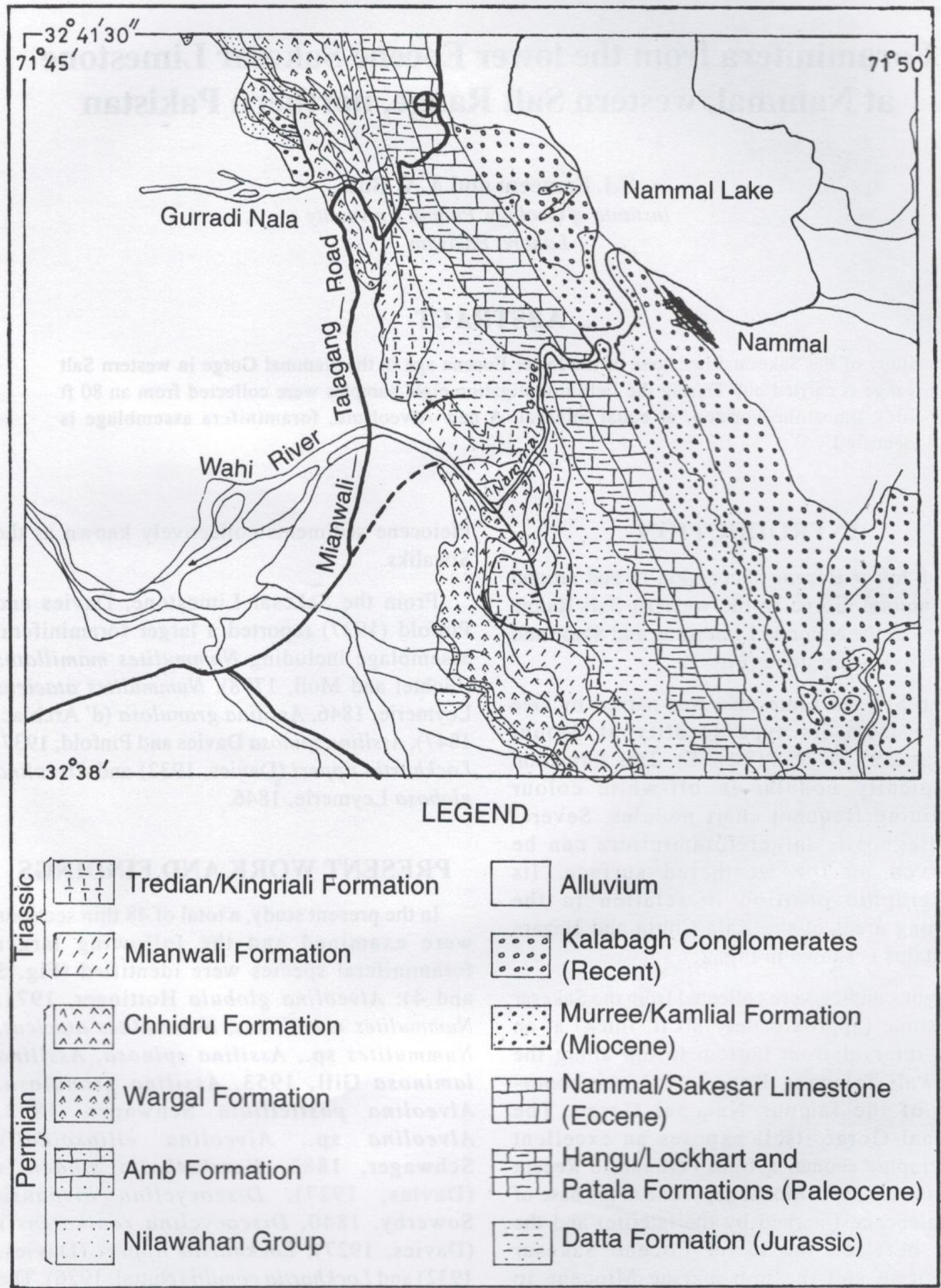

Fig. 1: Geological map of the Nammal area, Salt Range (after Gee, 1980). 
Foraminifera from the lower Eocene Sakesar Limestone at Nammal, western Salt Range

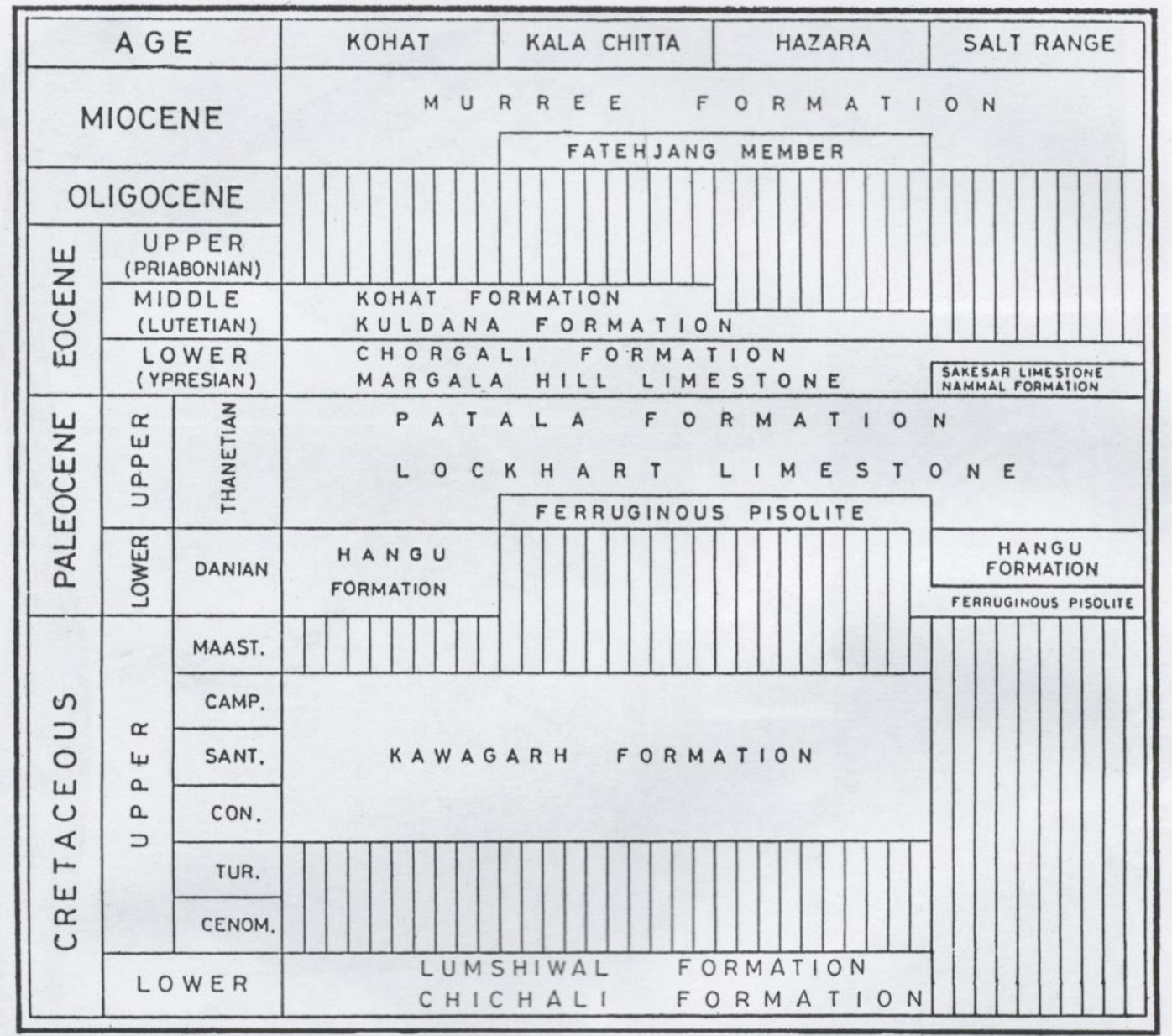

Fig. 2: Stratigraphic correlation of the Cretaceous-Tertiary succession of northern Pakistan.

Alveolina assemblage determined by the authors is found to be different from that of Davies and Pinfold (1937).

Hottinger (1971, P1. 1, Fig. E) reported the occurrence of Alveolina sp. from the Nammal Formation of the Salt Range. It is identified here as Alveolina ellipsoidalis. Hottinger (1971, P1. 3, Fig. A-B) also reported Alveolina pasticiltata from the Meting Limestone in Sind. On the basis of Alveolinid zonation, Hottinger (1971) had placed both the Nammal Formation and the Meting Limestone in the Paleocene in his correlation chart, while these formations are, however, part of the Eocene succession in Pakistan.
Moreover, Alveolina ellipsoidalis and Alveolina globula Hottinger, 1971 are recorded from the lower Eocene foraminiferal assemblage of the Sakesar Limestone, which overlies the Nammal Formation.

\section{CONCLUSION}

A new Alveolina assemblage including several age-diagnostic species is determined. Further study of the foraminiferal biostratigraphy of the lower Eocene succession of the Salt Range is strongly recommended to correlate and define the age of the similar rock units. 
S.J. Sameeni and A.A. Butt

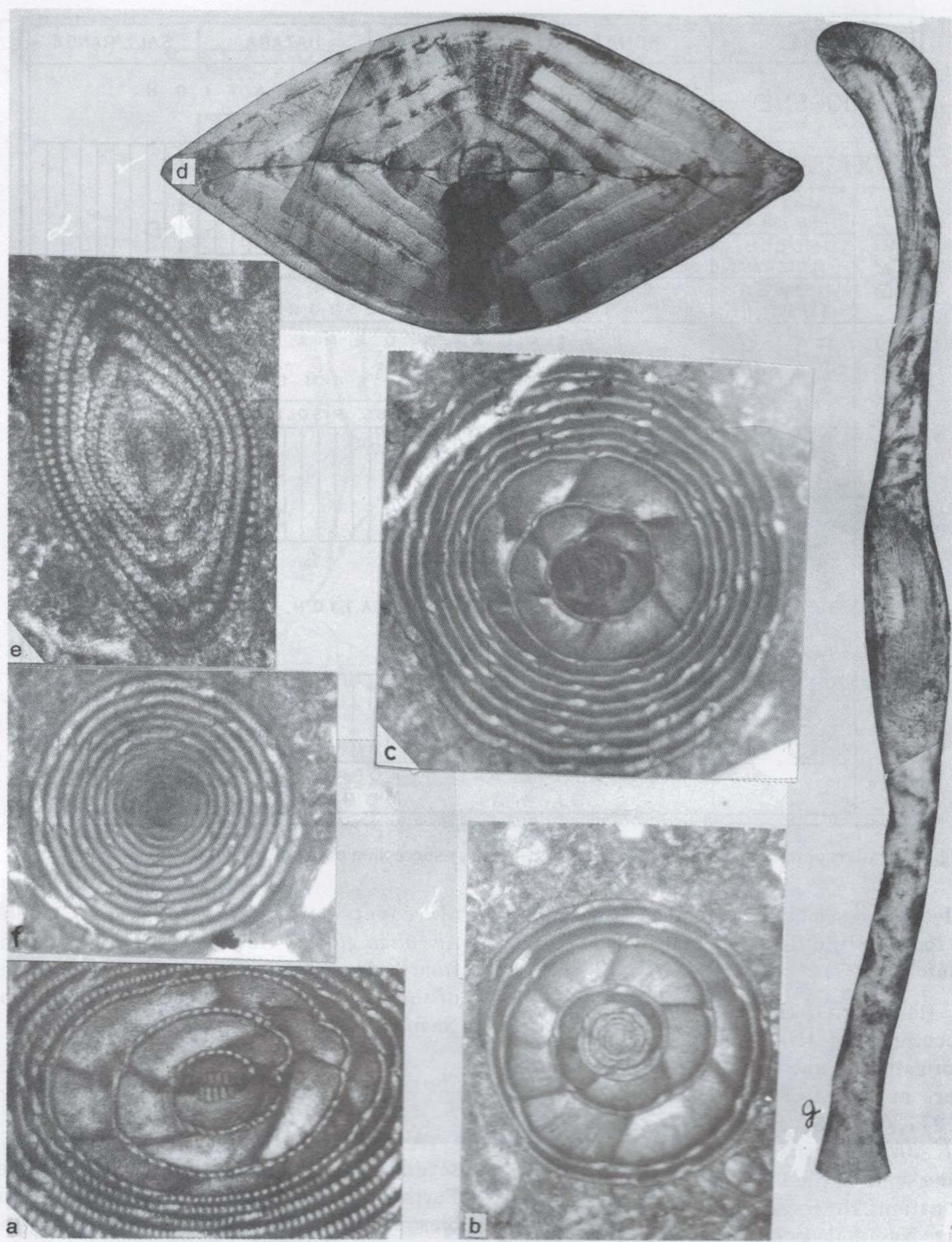

Fig. 3: a: Alveolina globula Hottinger x 30 (axial section), b-c: Alveolina globula Hottinger x 30 (equatorial section), d: Nummulites mamillatus (Fichtel and Moll) x 50; e: Alveolina ellipsoidalis Schwager x 30, f: Alveolina sp.; g: Ranikothalia sindensis (Davies) x 50 
Foraminifera from the lower Eocene Sakesar Limestone at Nammal, western Salt Range
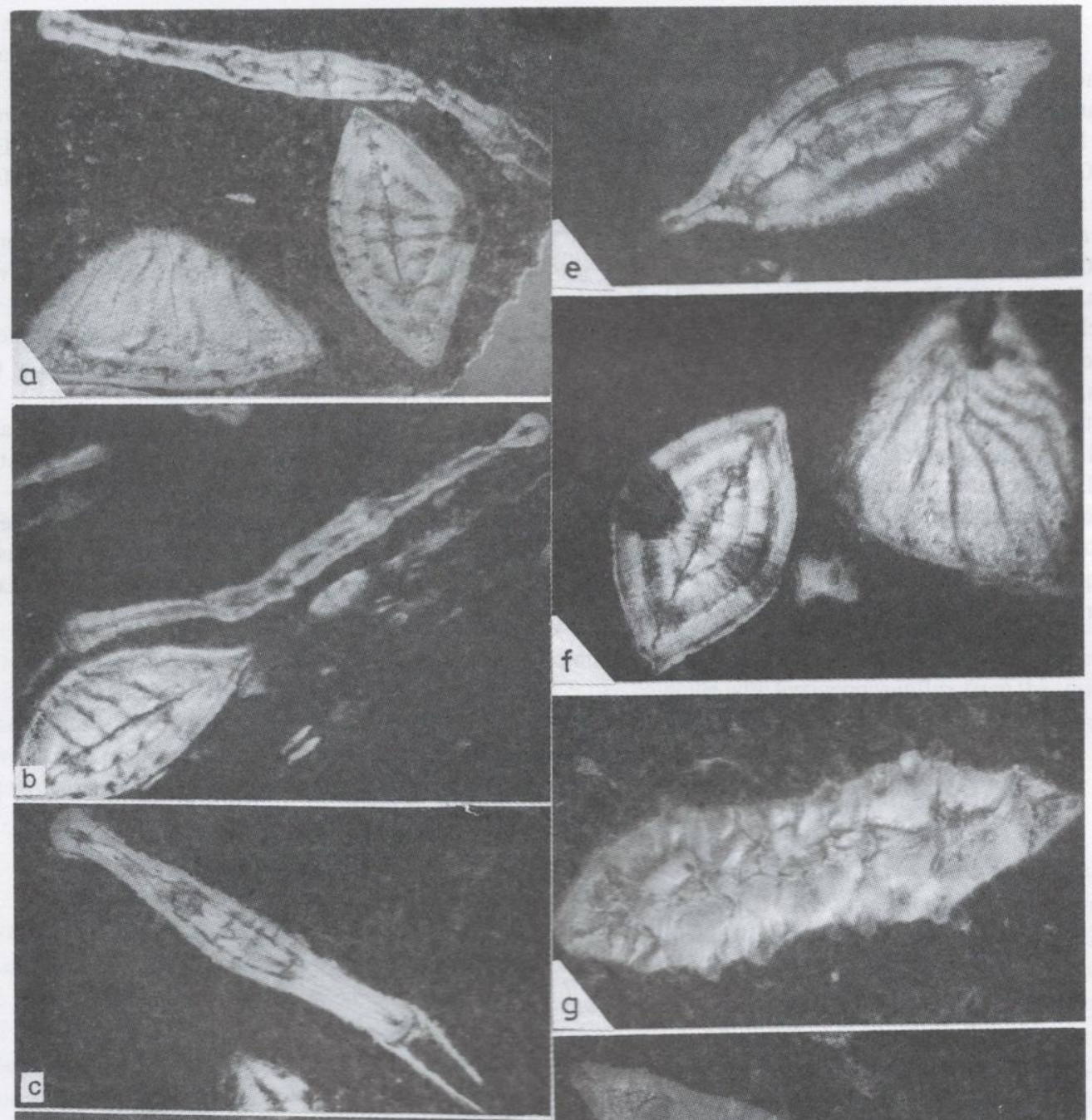

c
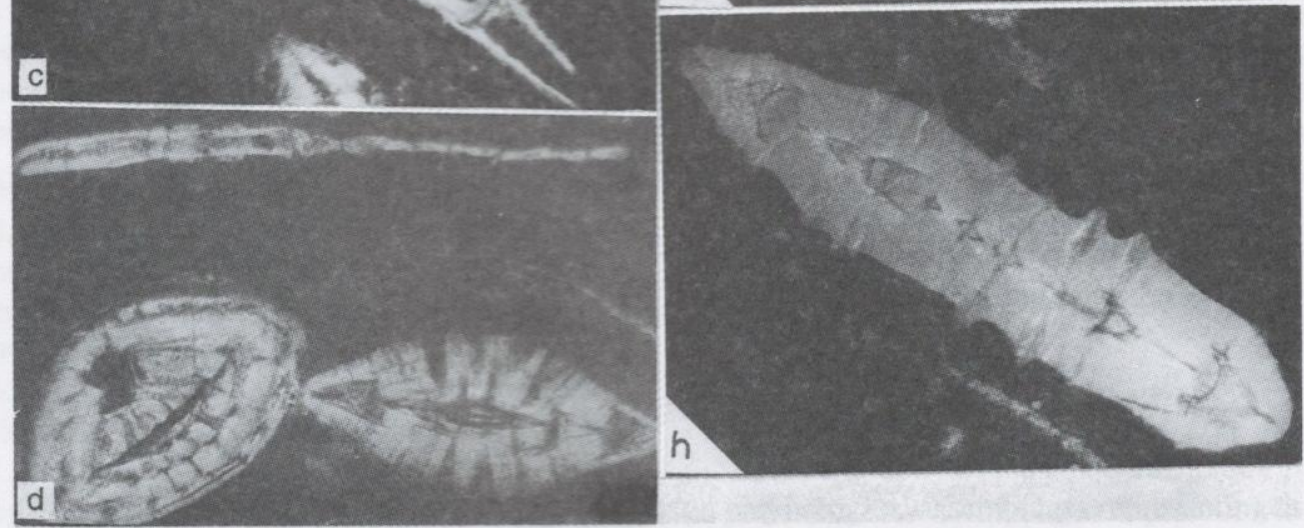

Fig. 4: a: Ranikothalia sindensis (Davies) x 30 (top), Nummulites mamillatus (Fichtel and Moll) x 30 (bottom); b: Nummulites mamillatus (Fichtel and Moll) x 30; c: Ranikothalia sindensis (Davies) x 30; d: Ranikothalia sindensis (Davies) x 30 (top): Nummulites mamillatus (Fichtel and Moll) x 30 (bottom left), Assilina laminosa Gill x 30 (bottom right); e: Nummulites sp. x 30; f: Nummulites mamillatus (Fichtel and Moll) x 30 showing septal filaments; g: Assilina spinosa Davies and Pinfold x 30; h: Assilina subspinosa Davies and Pinfold x 30. 


\section{REFERENCES}

Archiac, E.J.A. de, 1847, Memoir sur les fossiles des couches à nummulites des environs de Bayonne et de Dax. Mem. Soc. Geol. France, Ser. 2, v. 4, pp. 1006-1010.

Davies, L.M., 1927, The Ranikot beds at Thal. Quart. Jour. Geol. Soc., London, v. 83, pp. 260-290.

Davies, L.M., 1932, The genera dictyoconoides Nuttal, lockharartia nov. and rotalia Lamarck. Trans. Roy. Soc., Edinburgh, v. 57, 407 p.

Davies, L.M. and Pinfold, E.S., 1937, The Eocene beds of the Punjab Salt Range. Mem. Geol. Surv. India, Pal. Indica, New Ser. 24, pp. 1-79.

Fichtel, I. Von and Moll, J.P.C. Von, 1798, Testacea microscopica. pp. 53-54.

Gee, E.R., 1935, Recent observations on the Cambrian sequence of the Punjab Salt Range. Rec. Geol. Surv. India, v. 68(1), pp. 115-120.
Gill, W.D., 1953, The genus assilina in the Laki Series (lower Eocene) of the Kohat-Potwar basin, northern Pakistan. Contrib. Cushman Found. Foram. Res., v. 4, pp. 76-86.

Hottinger, L., 1971, Larger foraminifera common to Mediterranean and Indian Paleocene and Eocene formation. Ann. Inst. Geol. Publ. Hung., v. 54(4/1), pp. 145-151.

Leymerie, A., 1846, Mernoir sur le terrain à nummulites des Corbières. Mem. Soc. Geol. France, Ser. 2, v. 1, pp. 337-373.

Nuttal, W. L.F., 1926, The larger foraminifera of the upper Ranikot Series of Sind. Geol. Meg. London, v. 63, pp. 112-121.

Schwager C., 1883, Die foraminiferen ausden Eocaenablagerungen der Libyschen Wuste und Agyptens. Paleontographic, v. 30, pp. 81-153

Sowerby, J. de, 1840, Systematic list of organic remains. Appendix to Capt. Grant, C.W. Memoir to illustrate a geological map of Cutch. Trans. Geol. Soc., London, Ser. 2, v. 5, pp. 327-329. 